ЛИ ТЕРА Т У Р О В Е ДЕНИЕ

УДК 821.511 .142 .0

А. А. Арзамазов

МАНСИЙСКИЙ ПОЭТ АНДРЕЙ ТАРХАНОВ: РЕАЛИИ

И ПАРАДОКСЫ ХУДОЖЕСТВЕННОГО МИРОВИДЕНИЯ

В статье комплексно рассматривается поэтическое творчество классика мансийской литературы Андрея Тарханова. Определено местоположение национальной словесности в системе обширной межлитературной общности народов циркумполярной зоны, подчеркнута генетическая связанность художественной традиции манси с мифологическими представлениями, фольклором. Обозначены наиболее распространенные, творчески значимые темы и проблемы: выявлен большой авторский интерес к темам времени, истории, культурно-цивилизационной идентичности России, проанализирована индивидуально-авторская художественная панорама постсоветской эпохи, рассмотрены социальнопсихологические контексты переживания автором / лирическим субъектом современности. Отдельно исследуются сюжеты обращения Тарханова к русской литературе, уделено внимание изучению персонологического аспекта. В фокус исследования попадают многочисленные попытки А. Тарханова осмыслить в поэтической форме христианские нарративы, углубиться в аксиологию, в обрядовые традиции православия. При интерпретации корпуса текстов мансийского поэта учитывается и его языковой выбор, существенно редуцирующий ассоциативно-содержательные контексты соотнесенности со «своей», мансийской литературой. В целом, обозначены реалии и парадоксы художественного мировидения А. Тарханова, проявляющиеся как на образно-символическом уровне, так и в авторском выборе тем, ситуаций поэтической актуализации, эстетических ориентиров.

Андрей Тарханов по своей внутренней природе в меньшей степени, чем легендарный Юван Шесталов, был мансийским поэтом. Кажется, что он хотел вырваться из мансийского «замкнутого круга» и в то же время понимал, что творческий разрыв со своими корнями, этнокультурными истоками ощутимо отразится на качестве и оригинальности текстов. Поэту постоянно приходилось балансировать между русским и мансийским мирами, художественными ментальностями.

Ключевые слова: финно-угорские литературы, мансийская поэзия, образная система, лирический субъект, художественное сознание, двуязычие, этническая идентичность, традиционная культура, мифология, фольклор, система жанров.

DOI: $10.35634 / 2224-9443-2021-15-1-72-82$

Мансийская литература являет собой своеобразные «западные ворота» в обширную и многогранную межлитературную общность народов Крайнего Севера и Дальнего Востока. На фоне других литературных традиций заявленной культурно-территориальной зоны она отличается относительно большим количеством авторов, достаточно богатым художественным разнообразием. Манси, ханты в силу своего географического местоположения и наличия языковых «родственников», пожалуй, наиболее близкие Европе циркумполярные народы. Их этническую самобытность можно рассмотреть, не заглядывая в дебри бескрайней Сибири. Важно подчеркнуть, что мансийская и хантыйская литературы не одно десятилетие вызывали интерес в род- 
ственных европейских странах - прежде всего, в Венгрии. Венгеро-хантыйско-мансийские этногенетические, языковые, этноментальные параллели могут быть многоаспектно исследованы и на примере художественных текстов.

Мансийская литература, как и другие миноритарные литературы, восходит к национальному фольклору, который отличается многообразием жанровой структуры. К наиболее значимым жанрам относятся песни (эрыс), сказки (мойт), афористические формы (загадки (амыссь), пословицыпоговорки (ханисьтаплатныт-nотрыт) и др.). Первые художественные опыты мансийских авторов датируются концом 1920 - началом 1930-х гг. Произведения биографически-мемуарного характера печатались на страницах журналов «Тайга и тундра», «О нашей жизни», «Советский Север». Родоначальниками мансийской словесности считаются П. Чейметов-Еврин, М. Вахрушева (Баландина), М. Казанцев. Самый известный автор, писавший на мансийском языке, - Юван Шесталов (1937-2011); его произведения переведены на многие языки.

Андрей Семенович Тарханов (1936-2017), несмотря на статус русскоязычного писателя, безусловно, вписан в мансийскую художественную традицию и оценивается как мансийский национальный поэт. Биография А. Тарханова типична для представителя первого поколения этнической интеллигенции в СССР. У рожденного в отдаленном таежном поселении молодого человека была возможность учиться, расширять свои профессиональные знания. Возвращение на историческую родину, творческая реализация среди «своих», выход на уровень интенсивной межкультурной коммуникации - почти обязательные этапы выстраивания жизненного пути национального писателя. Сначала Тарханов хотел стать учителем: окончил Ханты-Мансийское педагогическое училище и даже успел поработать в школе. Учеба в Ленинградском педагогическом институте им. А. И. Герцена предложила иной «сценарий» личностного развития: Тарханов все больше осознавал свое литературное предназначение, уверенно начал делать литературную карьеру и еще при жизни получил широкую известность.

Андрей Тарханов - автор многочисленных поэтических сборников: «Зеленый дождь» (1975), «Праздник грома» (1981), «Морошковое лето» (1985), «Пасхальный день» (1993), «Поющие молнии» (2001), «Исповедь язычника» (2001), «Флейта иволги зовет» (2013) и др. Мы обратились к текстам из книги «День боренья» (2005), специально изданной к 70-летию поэта и включающей в себя большой объем стихотворений разных лет. Художественный феномен Андрея Тарханова рассмотрен нами в контексте отечественных [Арзамазов 2019; Жулева 2015, 2019; Ибрагимов 2018; Кучукова, Хараева 2018; Лагунова 2007; Султанов 2007, 2019; Хазанкович 2009, 2020] и зарубежных [Grönstrand 2014; Domokos 1983; Kurki 2018; Waite 2015; Yildiz 2012] исследований, посвященных национальным литературам, их большим и малым проблемам.

Стихотворения и поэмы А. Тарханова обычно датированы. Действительность своих произведений автор соотносит с внешним, жизненным, в широком смысле - социальным контекстом. Обозначая даты, он упорядочивает события, переживания, конкретизирует исторический фон. Примечательно, что поэт нередко «подтасовывает», смешивает свои хронологические ориентиры. Так, в некоторых текстах, датируемых 1970-1980 гг., внезапно появляются понятия из «лихих» $1990-\mathbf{x}$.

Тарханов - поэт, создающий традиционные рифмованные стихи и избегающий приближения к каким-либо экспериментальным формам. С точки зрения композиции его тексты довольно однообразны. Категория рифмы для него - данность, вне какой-либо художественной рефлексии. Тарханов не задумывается об оригинальности, поэтическом качестве своей рифмы. Иногда начинает казаться, что он играет в обескураживающую простоту стиха, очень хочет быть понятным для всех. Стихи Тарханова отличаются большим текстовым объемом: автор рассказывает истории, в развернутой форме делится своими оценками происходящего, выписывает панораму современности, творчески осмысляет сюжеты русской и мировой литературы,

Отдельного упоминания заслуживает тот факт, что для творческой практики поэт выбирает русский язык. А. Тарханов рос в мансийской языковой среде; для него, казалось бы, было более естественно творить на родном языке. Перейдя на русский, Тарханов не просто в значительной степени редуцировал образно-ассоциативные связи с духовной культурой, мировоззрени- 
ем манси, но попал в орбиту притяжения, влияния русской и советской литератур. Он стал одним из очень многих, лишил себя полноценной возможности формировать национальную художественную традицию. Тарханов считал, что выбор для творческой практики языка Пушкина и Толстого не отрывает писателя от своей культуры, концептосферы, напротив - это движение в сторону взаимообогащения литератур, картин мира.

А. Тарханов - автор, остро реагирующий на события современности. Поэту было очень сложно принять факт крушения СССР, смириться с новой непрозрачной действительностью и ее реалиями. При этом векторы внешней жизни, карьерного движения и внутреннего переживания происходящих в обществе изменений ощутимо расходятся. Поэт в 1990 - нач. 2000-х гг. не просто продолжает активно творить (создает новые произведения, публикует книги) - он становится все более влиятельной фигурой в информационном пространстве, в культурном ландшафте Югры, финно-угорского мира. Просыпаются политические амбиции; он открыто и остро высказывается о наболевшем, критикует институции власти; часто в своих публицистических выступлениях придерживается конструктивной тематики. «За кадром» в значительной степени остаются драматическое осознание поэтом краха прежних идей и идеалов, культурных кодов, ощущение философско-эстетического тупика. Тарханову очень сложно и одновременно интересно в реалиях нового времени; он не всегда знает, на что опираться, к каким ценностям, духовным категориям, символам апеллировать. Эта контрастирующая с его привычной личностной самоуверенностью творчески проявляющаяся растерянность прочитывается во многих его стихах, «сквозит» в образах и интонациях. Иногда она перерастает в неприкрытую агрессию, конфронтацию с коллективным субъектом наступившей, но не поддающейся пониманию эпохи.

В творчестве Андрея Тарханова немало текстов, иллюстрирующих социальное и экономическое неблагополучие постсоветской России. Эти произведения пронизаны болью, обидой, стыдом, желанием самоустраниться - прежде такого не было. В стихотворении «На автобусной остановке» воссоздаются полуслучайные фрагменты современности. Встреченные лирическим героем на остановке незнакомые люди как бы несут на себе печать нового времени. Они потеряны, заблудились в жизни. Поэт их ни в чем не винит. Виновата новая Россия: «Плачет ребенок в руках / Девочки / В курточке летней. / Стала случайною - ax! - / Мамой пятнадцатилетней. / Парень понурясь стоит, / Жизнь-то нелегкая, видно. / Хрупкий, ранимый на вид, - / Выдержит ли обиды?.. / Пьяный мужчина несет / Водку с начинкой заморской. / Выпьет - опять упадет...» [Тарханов $2005,31]$. Позиция наблюдателя дает лирическому «Я» возможность одновременно и отстраненно, и сопереживая, пропуская через себя, осмысливать и описывать происходящие события, прицельно фиксировать бедность и безысходность. Тексты, обращенные к 1990-м гг., у мансийского поэта получились беспощадно документальными, художественно выразительными.

Тарханова очень тревожат резко возникшие социальное неравенство, расслоение общества. Он прекрасно понимает, что сам теряет финансовую стабильность, становится малоимущим, постепенно оказывается на обочине новой жизни. Поэты, тем более представляющие национальные литературы, языки, беззащитны и не приспособлены к жестким реалиям 1990-х. Творческому, интеллектуальному самовыражению противостоит «мышление ларька»: «Внедряется ларьковое мышление / В тебя, меня, невинных малышей: / «Имей ларек - / И в нем найдешь спасение / От нищих, от обиженных людей. / Имей ларек - / И станешь ты удачливым, / Потом миллионером станешь ты. / И девушки к тебе повалят пачками, / Ведь доллар - как магнит для красоты...» [Тарханов 2005, 22]. В цитируемом тексте просматривается частая в творчестве А. Тарханова тема греховно-продажной любви. Лирического героя сначала отталкивает такое положение вещей: любовь, нежность, страсть в его понимании не должны продаватьсяпокупаться. Однако подобная точка зрения, степень ее твердости вполне могут смягчаться и даже - пересматриваться. Для рожденного в «вегетарианском» в плане секса Советском Союзе новые чувственно-телесные возможности начинают казаться все более привлекательными и заманчивыми. Вслед за первоначальным отторжением приходит интерес.

Для развернутого поэтического изображения 1990-х гг. А. Тарханов использует специальные характерологические локусы. Среди них - образ ночного ресторана. В художествен- 
ном мире мансийского поэта это не место «про еду», а символический притон, средоточие сладострастия и греха, олицетворение легкоусваиваемых, доступных новых ценностей. Именно в ресторане лирический герой познает непознанное, превращается в полноправного участника всеобщего дионисийского веселья, карнавала, становится адептом «невыносимой легкости бытия»: «Нынче праздник - ночной ресторан. / Скрипки плачут, / А флейты смеются. / Здесь желаньям потехи найдутся, / Здесь веселые дамы пасутся, / Здесь красивые тайны куются, / Ложь хохочет, / Танцует обман... / Нынче праздник - ночной ресторан. / И с тобой, незнакомка, мне мило. / Ты потемки мои осветила, / Для любви твой качается стан...» [Тарханов 2005, 21]. Обман, легкая неискренняя веселость, фальшивая приподнятость духа, доступность запретного, состояние опьяненности, спутанность сознания, потеря жизненных ориентиров, - поэтически улавливаемые приметы переживаемой мансийским автором эпохи.

Лирический герой, уязвленный «лихими» 1990-ми, находится на перепутье. Он постоянно испытывает потребность очиститься от грязи приобретенного неоднозначного экзистенциального опыта. Спасение при этом возможно в провинции, в мансийской тайге, где нет вызовов, искусов, соблазнов. И вместе с тем «Я»-субъект, явленный в ипостаси поэта, жаждет вдохновения, немыслимого вне «греховной пены» существования. Отрезанный от столиц западносибирскими снегами, он боится сорваться, уйти «на дно» удовольствий, стать заложником разгульного безумия. Поэт в данном случае оперирует хорошо узнаваемыми символами описываемой действительности: «Я в избушке живу у ручья. / Нет ларьков, казино и сберкассы, / Нет путан, нет разбойничьей трассы, / Лес гармонией лечит меня. / Удивительно яркую грусть / Навевают зимою сугробы... / Одного в эту пору боюсь - / Вдруг вернусь на разгульные тропы...» [Тарханов 2005, 17].

Воплощающим устои и реалии 1990-х гг. городом у А. Тарханова объявляется Москва, которая нередко противостоит тихому провинциальному Ханты-Мансийску. Столица России изображается как город бесов: «А в Москве скрипучи бесы - / Как в болоте сухостой: / «Не нужны нам сказки-песни, / Дайте шоу с наготой! / Пусть гремит в ночах эстрада! / Пусть хохочет казино!..» [Тарханов 2005, 241]. Постсоветская Москва ассоциируется в стихотворениях А. Тарханова с болезнью, олицетворяет собой внешнюю и внутреннюю смуту, интриги, ложь, страх. Лирический герой, окунувшись в атмосферу всеобщего разложения, старается как можно быстрее уехать, вернуться на малую родину: «Когда-то я спешил к тебе, столица, / Была ты шумной славою страны. / А нынче ты - огромная больница, / Где москвичи измученно больны. / В сердца людей вселились боль и смута. / Громадный город - беспощадный спрут. / Здесь корни мафий, заговоров, блуда, / Здесь в высших кабинетах вечно врут... / Мое спасенье - здесь я ненадолго. / Уже я болен. Дума горяча. / Но, слава Богу, есть Сибирь...» [Тарханов 2005, 115]. В приведенном тексте проявляется сложность отношения этнофора, уроженца Сибири к Москве, глухой и равнодушной, не желающей знать о проблемах и бедах большой страны.

Андрей Тарханов создал немало стихотворений, посвященных взаимоотношениям мужчины и женщины. В его творчестве видное место занимает любовная лирика. Тексты мансийского поэта о личном, о любви с точки зрения содержания, представленных сценариев нельзя назвать типичными, стандартными для литературных традиций народов России. У Тарханова отсутствуют произведения, сюжетно демонстрирующие ценности тихой семейной жизни. Для него, по-видимому, это пресно и скучно. В центре его художественного внимания - отношения сложные, порочные. В их основе - меркантильные интересы женщины, ее желание причинить мужчине боль. Женщина в произведениях А. Тарханова обычно расчетлива, жестока, злопамятна. Ее чувства - если они возникают - не длятся долго. В тексте «Желанный праздник миновал в разлуке» лирический герой осмысливает факт женской измены: «Ты в этот час была в чужом застолье, / Не ведая суровых глаз Судьбы, / Которые с твоих родных раздолий / Смотрели на тебя из темноты. / Измену не простят тебе ни боги, / Ни мать, идя в раздумье по росе. / И что за люди на твоей дороге - / С коварною ухмылкой на лице? / Ты с ними заодно. Ты их партнер...» [Тарханов 2005, 231]. Несчастная любовь в данном случае хронологически «совпа- 
ла» с 1990-ми, в авторском восприятии - временем «обнуления» больших искренних чувств, бескорыстности симпатий и сближений. В стихотворении «Не спешите, друзья, расставаться» [Тарханов 2005, 250] женщина выбирает не надежность семейного уюта, а «разгульные страсти». Она жертва современности, новых социальных обстоятельств, психологических установок. Любимая женщина уходит от лирического героя и в стихотворении «Сквозь дождь пламенеют рябины» [Тарханов 2005, 210]. Он приходит к выводу, что самая надежная из женщин - мама. Остальным доверять нельзя.

«Я»-субъект - поэт - не может соответствовать социальным и финансовым запросам возлюбленной, которой нужны не чувства и стихи, а материальные ценности. Любовь в системе координат и ориентиров нового времени утрачивает свою первостепенность: «Уж год околдован Тобою, / Сияньем распахнутых глаз. / Но... что называли любовью, / Сегодня уже не для нас. / Засыпаны пеплом признанья / Наивность и наши мечты. / Живешь ты другим ожиданьем, / Желаешь дворец и сады...» [Тарханов 2005, 210].

Одним из продуктивных в поэтическом творчестве А. Тарханова является мотив одиночества места / человека. Забытые всеми локусы, люди поэту кажутся особенными: просто так не забывают, не оставляют. Факт забытости, заброшенности выступает своеобразным эквивалентом знаковости, сакральности. В стихотворении «Избушка» [Тарханов 2005, 45] речь идет о последнем доме в когда-то большом мансийском поселении. Одинокая изба в данном случае не только символ объективного неправильного течения жизни, неоптимального, с точки зрения автора-этнофора, движения человеческой цивилизации. Это метафора исчезающего народа, оставшегося наедине с самим собой, со своими этническими воспоминаниями. Еще один просматривающийся угол сравнительного преломления - забытая, оставленная изба ассоциируется с одинокой несчастной женщиной. В тексте «Скит» перед читателем предстает старец-схимник, отрезанный от большого мира тайгой. Наедине с собой, с Богом он нашел умиротворение, его жизнь наполнена светом веры. Поэт приходит к мысли, что смирение, ограничения, одухотворенная скромность продлевают годы жизни. В тексте используется большое количество эпитетов, описывающих место и человека: «Зеленую крышу скита / Не видно в лесу даже птицам. / Зеленые всюду цвета, / Лишь рыжие половицы. / Сухой, словно ветка, старик / Не ходит, а словно летает. / Глаза студены и тихи, / А ноги и руки крепки... / Чернеют иконы в углах, / И всюду - пахучие травы...» [Тарханов 2005, 101]. При рассмотрении этого и многих других лирических произведений можно сделать вывод о знаковости и высокой степени актуализации категории эпитета в системе поэтического языка А. Тарханова. В этом смысле поэт избрал относительно «легкую» стратегию обустройства своих художественных текстов.

В поэтической модели А. Тарханова видное место занимают так называемые «чужие ландшафты». Мансийского поэта можно смело назвать homomobilis. Его трудно было застать в родном Ханты-Мансийске. Он постоянно пребывал в разъездах, осваивая новые территории и коммуницируя с представителями советско-российской и иногда западной творческоинтеллектуальной элиты. Путешествия поэта по России и за ее пределами не могли не запечатлеться в художественном слове.

К геопоэтическим произведениям Тарханова относится стихотворение «Крым» [Тарханов $2005,178]$. В целом, это проходное стихотворение, в котором нет ни ярко-оригинальной передачи южной природной панорамы, ни выраженного интертекстуального соприкосновения с «крымским текстом» русской литературы. Для поэта заявленные крымские сюжеты оказались чрезмерно сложными, требующими активации обширного культурного фона, непознанных чужих символов и смыслов. Несколько больше художественного напряжения, авторского участия в другом «южном» стихотворении «С печалью о Грузии». Здесь в основе сюжета не реальное путешествие, а виртуально-сочувственное приближение к происходящему в Грузии политическому перевороту. Тарханова сильно задела «революция роз». Он наблюдает за событиями со стороны, воспринимает случившееся в трагическом контексте краха старого надежного совет- 
ского мира, когда граждане одной страны оказываются по разные стороны баррикад: «Звучат Кварели, Марнеули, / Дманиси, Гори, Гурджани... / В тумане города, аулы, / Великие для сердца дни. / Согласья нету в стане сильных, / И мира нет среди вождей. / Глядят задумчиво грузины / На башни вечные царей. / Кругом сады, цветенье, горы, / И Божий храм, и свет его. / Но почему в народе горе?.. / О ком ты плачешь, Сулико?..» [Тарханов 2005, 208].

Еще одно мысленно-эмоциональное преодоление пространства и времени представлено в тексте «Рожденный цунами». Поэт отзывается на катастрофические события 2004 г. в ЮгоВосточной Азии. Стихотворение отличается усиленным визуальным фоном: речь может идти о поэтизации увиденных автором видеоматических кадров, о семиотическом перекрестье плоскостей восприятия и выражения. При этом планы действия в произведении как бы смешиваются, накладываются друг на друга. Ощущение, переживание мгновений разгула сметающей все на своем пути стихии океана никогда не отпустят сознание: для лирического героя это навсегда «реальность реальности», которую уже не отменить, не изжить. Эта непрерывная, ничем не перебиваемая акцентированная соотнесенность прошлого и настоящего в тексте фиксируется и на грамматическом уровне: настоящее время в равной степени сосуществует с глагольными формами прошедшего времени. Событийно-ситуативная насыщенность сюжета, переключение темпоральностей создают эффект некоторой затемненности произошедшего: мансийский поэт пытается художественно описать сложные психологические реакции субъекта-очевидца цунами, когда горе осознания еще впереди. На фоне многих других текстов А. Тарханова рассматриваемое произведение кажется интересным, оригинальным: «Мальчик плачет и смотрит на маму, / Он в глазах ее видит цунами. / Только высказать чувства не может, / Он сейчас на цыпленка похожий. / Он дрожит. / Почему же из мамы / Не уходит тот страшный цунами? / Он за всех своих сверстников плачет, / Прижимая к груди алый мячик. / Этот мячик, притихшее море, / Подарило ему словно горе. / Он нашел его после цунами. / И увидел бегущую маму. / Он вначале... и не удивился, / Он ведь заново нынче родился. / Помнит - нету ни облак, ни мамы, - / Только белая пена цунами. / Он, как мячик, по пляжу катился, / Очень долго... Он снова родился» [Тарханов 2005, 55].

Художественное впечатление «живого» путешествия - в стихотворении «В Загорье». Лирический герой посещает малую родину русского поэта Александра Твардовского. Это пространство оказывается насквозь пронизанным литературными аллюзиями, из реального в авторском восприятии оно превращается в мифологическое. Оно, с одной стороны, воплощает собой идеально-собирательный среднерусский пейзаж, с другой - обычных сельских людей здесь замещают персонажи произведений Твардовского (Василий Теркин, роты солдат и т.д.): «С небес сиянье голубое льется, / На родину Твардовского дивлюсь. / Он воду пил из древнего колодца, / Я от души святой воды напьюсь. / Вокруг березы водят хороводы, / И дом поэта Теркин бережет. / Сюда идут невидимые роты...» [Тарханов 2005, 192]. Тарханов пытается подражать русскому поэту на лексическом уровне. Глагол «дивлюсь», по-видимому, генетически восходящий к западной группе говоров южнорусского наречия, - возможная отсылка не только к стилю Твардовского, но и к народному языку. Смоленская сторона для мансийского поэта - священная земля войны; ее жители - герои, принявшие на себя самые сокрушительные удары немецкой армии.

Для Андрея Тарханова очень важно на разных уровнях поэтического творчества проявлять соотнесенность с большой русской словесностью. Выбрав русский язык в качестве основного, мансийский поэт не мог не ориентироваться на образцы русской лирики. Примечательной чертой творчества А. Тарханова можно считать стихотворное воссоздание образов русских поэтов. Он пытается сквозь столетия заглянуть в их судьбы, остановить мгновения их реальности. В тексте «У моря костерок горит» [Тарханов 2005, 124] приводится сцена возрождениявозвращения Михаила Лермонтова. Михаил Юрьевич обладает уникальными знаниями относительно своего будущего, делится своими переживаниями с собравшимися у символического костра другими поэтами. Образ Лермонтова фигурирует и в стихотворении «Знак печали». 
Для А. Тарханова именно Лермонтов олицетворяет собой настоящего русского поэта, живущего высокими идеалами творчества. При всей несхожести лирических темпераментов, Тарханову очень хочется походить на русского классика. В данном случае авторское внимание снова фокусируется на деталях внешности: у поэтов - «задумчивых людей» - глаза особого цвета и содержания: «Самые красивые печали / В жизни у задумчивых людей. / И глаза у них обычно кари, / Или синие, как у морей...» [Тарханов 2005, 116]. В стихотворении образ Лермонтова вписан в морской пейзаж: на горизонте его «встречают» паруса, он печально всматривается в сине-белые просторы. Нельзя не обратить внимания на некоторую упрощенность, художественную нераскрытость моделируемой ситуации. Заявленный сюжет распадается на плохо связанные друг с другом содержательно эпизоды; поэтически создаваемый образ кажется неубедительным.

В произведении «Рушит время любое жилье» мансийский поэт «наблюдает» предсмертные мгновения жизни Афанасия Фета. Творчески крепкий дух здесь противопоставляется телесному угасанию. Вдохновенье может отсрочить неминуемую смерть: «Рушит время любое жилье, / Но душа... это тайна от Бога. / Плоть слаба. / Угасанье ее / Первым видит небесное око. / И когда умирающий Фет / От огня вдохновенья воспрянул, / Посуровел веселый рассвет: / «Воскрешать Вашу плоть я не стану». / Удивился признанью поэт. / А рука все дрожала, дрожала... / Согласиться душа не желала / С тем, что высказал нынче рассвет...» [Тарханов 2005, 183]. Рассматриваемое стихотворение нельзя назвать удачным: отдельные его образные детали, реплики, формулировки с художественной точки зрения очень уязвимы.

Сущность поэзии, «слагаемые» поэтического дара, внутренние миры поэта - темы постоянной рефлексии А. Тарханова. Он как будто все время пытается себе доказать, что относится к этой когорте избранных. У Тарханова своя философия стихотворения: для каждого поэта характерны борьба, сосуществование двух начал - высокого и низкого, святого и греховного. В стихотворении «Два человека» утверждается, что «поэт - это два человека. Один от небесного света, другой от греховной земли» [Тарханов 2005, 49]. Один наделен подлинным талантом, другой «завистливо» берет упрямством, патологической работоспособностью. При этом автор уклоняется от открытого самоопределения.

Поэт в художественном представлении Тарханова - далекий от меркантильных интересов земной жизни человек. Он не отмира сего, его поведение, умозаключения наивно-отталкивающие, не принимаемые большинством. В тексте «Базар всегда его смущает» личность поэта противопоставлена далекому от искусства духу новой эпохи 1990-х. Вместо того, чтобы по-прежнему оставаться страной поэзии, Россия стала страной базаров: «Базар всегда его смущает, / Он волноваться заставляет. / Возле цветов он ходит, ходит. / И на торговок гнев наводит. / - Ну, что ты мельтешишь, мужчина?! / Не видел, что ли, георгина?! / - Есть в белом георгине вьюга...» [Тарханов 2005, 56]. Российский базар 1990-х гг. - один из ключевых урбанистических образов поэзии А. Тарханова - пространство обмана, ложных ценностей, хамства, равнодушия. Для Тарханова поэт ожидаемо больше, чем поэт. Он посланник Бога, его духовная миссия - примирить человеческие «снега» и «пожары»: «И думал Бог: не даст мне зло / Гармонию восстановить на свете. / И...озарение пришло - / И создал Бог тогда поэтов...» [Тарханов 2005, 104].

Тарханов, повышая значимость литературы, значение писателя в социальной иерархии современности, пытается сопротивляться новым правилам игры, обесценивающим культуру, искусство. Поэт остро переживает обесценивание литературы, снижение статуса представителя творческой интеллигенции.

Одно из центральных мест в художественной системе Андрея Тарханова занимают христианские сюжеты, тема веры. Для национальных писателей Крайнего Севера и Дальнего Востока это нехарактерный творческий выбор. Вместо естественного обращения к мифологическим ресурсам своего этноса, поэтизации обширного, глубоко оригинального фольклорного материала мансийский поэт пытается в стихах активировать христианскую составляющую. По всей вероятности, А. Тарханов таким образом хотел приблизиться к мировой куль- 
туре, показать свои художественно-ассоциативные связи с европейской цивилизацией, с русской моделью мира. Христианство для него - одно из фундаментальных начал литературы, поэзии. Примечательно, что в своих христианских авторских «прочтениях» поэт не заходит слишком далеко, избегает актуализации семиотически концентрированной христианской сюжетики.

Россия в художественном освещении Тарханова - страна Божья, русский народ находится под защитой Всевышнего. В стихотворении «Встречное пламя» [Тарханов 2005, 23-24] напавшие на Русь язычники пытаются спалить храм. Их поражает небесный огонь; враги христианства обращаются в пепел. В текстах А. Тарханова символическое значение приписывается ожиданию больших христианских праздников. В произведении «Воскресная верба» [Тарханов 2005, 100] растению придаются человеческие свойства: верба ждет Пасху, готовится подарить свою красоту верующим людям. В предпасхальные дни лирический герой верит в лучшее, пребывает в ожидании чудес. Ожиданием Пасхи пронизано стихотворение «Лазоревая суббота» [Тарханов 2005, 225]. В преддверии праздника просыпается природа, начинают таять снега. Внешние преобразования совпадают с изменениями внутренними: люди в Пасху становятся добрее, мягче, искреннее. Относительно веры в Бога Тарханов придерживается риторической позиции максимальной открытости. Вера для него не является интимной категорией бытия, о ней можно и нужно говорить громко. Бог помогает лирическому герою в тяжелые минуты, вера становится последним спасительным светом: «И пришел я, озябший, к порогу, / И упал, от бессилья дрожа. / Но уже по велению Бога / Оклемалась, воспряла душа. / Много раз и страдая, и маясь, / Шел я в жизни на свой огонек. / И уже умирал, задыхаясь, / Но...всегда выручал меня Бог» [Тарханов 2005, 226].

На наш взгляд, единственным выразительным опытом приближения к библейскому тексту можно считать стихотворение «Христос в пустыне» [Тарханов 2005, 268-269]. Поэтическое «скольжение» по библейской сюжетике у Тарханова проходит с трудом. Образ Христа не поддается художественной интерпретации - он лишен экзистенциальной глубины и исторической достоверности. Данный пример еще раз показывает, что у многих национальных писателей применительно к чужим культурно насыщенным знаковым системам срабатывают внутренние ограничения. Образно-эстетическое пространство «другого» при этом рождает у поэта чувство художественного любопытства, зовет сделать шаг навстречу и в то же время начинает давить сложной «суммой» текстов, контекстов, незнакомых условностей, символических кодов.

В плане выстраивания литературной карьеры А. Тарханов оказался более «взрослым», чем большинство «циркумполярных» писателей. Поэтический «наив» мансийского автора прагматичен: чаще это осознанно преподносимый художественный код. Нельзя не заметить, что в тематическом аспекте поэзия Тарханова очень разная. Он не поэт только одной магистральной темы, одной концептуальной проблемы. Его творческую концепцию определяют широта лирических ситуаций, привлекаемых образов, многообразие персонажей, ландшафтов. Однако подобная «горизонталь» интересов влечет за собой «рассеивание» художественной энергии, проявляется поверхностное отношение к поэтически интерпретируемому материалу. Андрей Тарханов при всей своей одаренности оказался «всеядным» автором.

Неожиданным кажется повышенное авторское внимание к христианству. От мансийского поэта ждешь содержательных языческих проекций, художественного раскрытия мифологической символики. Тарханов часто отдает предпочтение элементам мировоззрения, сближающим его миротексты с русской культурой, словесностью. Он в своем творчестве далеко ушел от манифестаций шаманизма соплеменника Ювана Шесталова. Андрей Тарханов, как и, например, корякский поэт Владимир Коянто, был увлечен осмыслением исторического процесса, исследованием языков, образов современности. Психологические портреты, особенности социального поведения людей новой эпохи становятся важными сферами изображения. 


\section{ЛИТЕРАТУРА}

Арзамазов А. А. Пути развития «миноритарной» литературы: поэзия ненца Прокопия Явтысого // Ежегодник финно-угорских исследований, 2019. Т. 13. Вып. 4. С. 623-632.

Жулева А. С. Мифопоэтическая модель мира в ненецкой литературе. М.: ИМЛИ РАН, 2019. 328 с.

Жулева A. С. Поэтика пространства в ненецкой литературе // История национальных литератур. Перечитывая и переосмысливая. Вып. V. М.: ИМЛИ РАН, 2015. С. 97-153.

Ибрагимов М. И. Национальная идентичность татарской литературы: современные методы исследования. Казань: ИЯЛИ им. Г. Ибрагимова, 2018. 104 с.

Кучукова 3. А., Хараева Л. Ф. Гендер и этногендер (на материале кабардинской женской прозы). Нальчик: Изд. «Принт Центр», 2018. 192 с.

Лагунова $О . K$. Феномен творчества русскоязычных писателей ненцев и хантов последней трети ХХ века (Е. Айпин, Ю. Вэлла, А. Неркаги). Тюмень: Изд-во Тюменского гос. ун-та, 2007. 258 с.

Султанов $K$. К. От Дома к Миру. Этнонациональная идентичность в литературе и межкультурный диалог. М.: Наука, 2007. 302 с.

Султанов $К . К$. Угол преломления. Литература и идентичность: коммуникативный аспект. М.: ИМЛИ РАН, 2019. 352 с.

Тарханов А. День боренья: Стихи, поэмы. Екатеринбург: Средне-Уральское книжное издательство, 2005. $319 \mathrm{c}$.

Хазанкович Ю. Г. Фольклорно-эпические традиции в прозе малочисленных народов Севера. Новосибирск: Изд-во СО РАН, 2009. 131 с.

Хазанкович Ю. Г. Эпические традиции в прозе коренных малочисленных народов Арктики. М.: Флинта, 2020. 416 c.

Domokos $P$. Itäisten suomalais-ugrilaisten kansojen kirjallisuudesta. Porvoo: SKS, 1983. 179 p.

Grönstrand H. Self-translating: linking languages, literary traditions and cultural spheres // Cosmopolitanism and Transnationalism: Visions, Ethics and Practices.Vol. 15. Helsinki: Helsinki Collegium for Advanced Studies. 2014. P. 116-137.

Kurki T. Rajan kirjailijat. Venäjän Karjalan suomenkieliset kirjailijat tilan ja identiteetin kirjoittajina. Helsinki: SKS, 2018. 436 p.

Waite G. Nancy Huston's Polyglot Texts: Linguistic Limits and Transgressions // L2 Journal. 2015. Vol. 7. P. 102-113.

Yildiz Y. Beyond the mother tongue. The postmonolingual condition. New York: Fordham University Press, 2012. $306 \mathrm{p}$

Поступила в редакцию 09.12.2020

Арзамазов Алексей Андреевич, доктор филологических наук, ведущий научный сотрудник Удмуртский институт истории, языка и литературы УдмФИЦ УрО РАН, 426004, Россия, г. Ижевск, ул. Ломоносова, 4 доктор филологических наук, ведущий научный сотрудник Лаборатория многофакторного гуманитарного анализа и когнитивной филологии ФГБУН «Федеральный исследовательский центр «Казанский научный центр Российской Академии наук»»» 420111, Россия, г. Казань, ул. Лобачевского, 2/31 e-mail: arzami@rambler.ru 


\title{
A. A. Arzamazov \\ MANSI POET ANDREY TARKHANOV: \\ REALITIES AND PARADOXES OF THE ARTISTIC WORLD
}

\author{
DOI: $10.35634 / 2224-9443-2021-15-1-72-82$
}

The article comprehensively examines the poetry of the classic of Mansi literature Andrei Tarkhanov. The place of the national literature in the system of the vast interliterary community of the peoples of the circumpolar zone is determined, the genetic connection of the Mansi artistic tradition with mythological ideas and folklore is emphasized. The most common, creatively significant themes and problems are identified: a great author's interest in the themes of time, history, cultural and civilizational identity of Russia is shown, the individual author's artistic panorama of the post-Soviet era is analyzed, the socio-psychological contexts of the experience of the author / lyrical subject of modernity are considered. The plots of Tarkhanov's appeal to Russian literature are studied, attention is paid to the study of the personological aspect. The focus of the reading falls on the poet's numerous attempts to comprehend Christian narratives in poetry, to delve into the axiology and ritual practices of Orthodoxy. When we interpret the text corpus of the Mansi poet, we take into account his linguistic choice, which significantly reduces the associative and meaningful contexts with "his" Mansi literature. In general, the realities and paradoxes of A. Tarkhanov's artistic worldview are identified, which are manifested at the figurative-symbolic level and in the author's choice of themes, situations of poetic actualization and aesthetic guidelines.

Andrei Tarkhanov was less a Mansi poet in his inner nature than the legendary Yuvan Shestalov. It seems that he wanted to break out of the Mansi "vicious circle" and at the same time understood that a creative break with his roots, ethnocultural origins would significantly affect the quality and originality of his texts.He constantly had to balance between the Russian and Mansi worlds, artistic mentality.

Key words: Finno-Ugric literature, Mansi poetry, figurative system, lyrical subject, artistic consciousness, bilingualism, ethnic identity, traditional culture, mythology, folklore, genre system.

Citation: Yearbook of Finno-Ugric Studies, 2021, vol. 15, issue 1, pp. 72-82. In Russian.

\section{REFERENCES}

Arzamazov A. A. Puti razvitiya «minoritarnoi» literatury: poeziya nentsa Prokopiya Yavtysogo [Ways of development of "minority" literature: poetry of Nenets Procopiy Yavtysy]. Ezhegodnik finno-ugorskikh issledovanii [Yearbook of Finno-Ugric Studies], 2019, Vol. 13. Issue 4. Pp. 623-632. In Russian.

Zhuleva A. S. Mifopoeticheskaya model' mira v nenetskoi literature [Mythopoetic model of the world in the Nenets literature]. Moscow, IMLI RAN Publ., 2019. 328 p.In Russian.

Zhuleva A. S. Poetika prostranstva v nenetskoi literature [The poetics of space in the Nenets literature]. Istoriya natsional'nykh literatur. Perechityvaya i pereosmyslivaya. Vypusk $V$. [History of national literature. Rereading and rethinking]. Moscow, IMLI RAN Publ, 2015. Issue 5. Pp. 97-153. In Russian.

Ibragimov M. I. Natsional'naya identichnost' tatarskoi literatury: sovremennye metody issledovaniya [National identity of Tatar literature: modern research methods]. Kazan, IYaLI im. G. Ibragimova Publ., 2018. 104 p. In Russian.

Kuchukova Z. A., Kharaeva L. F. Gender i etnogender (na materiale kabardinskoi zhenskoi prozy) [Gender and ethnogender (based on the material of Kabardian women's prose)]. Nalchik, Izdatel'skaya tipografiya «Print Tsentr» Publ., 2018. 192 p. In Russian.

Lagunova O. K. Fenomen tvorchestva russkoyazychnykh pisatelei nentsev i khantov poslednei treti XX veka (E. Aipin, Yu. Vella, A. Nerkagi) [The phenomenon of creativity of the Russian-language Nenets and Khanty writers of the last third of the XX century (E. Aipin, Y. Vella, A. Nerkagi)]. Tyumen, Izd-vo Tyumenskogo gos. un-ta Publ., 2007. 258 p. In Russian.

Sultanov K. K. Ot Doma k Miru. Etnonatsional'naya identichnost' v literature i mezhkul'turnyi dialog [From home to the world. Ethno-national identity in literature and intercultural dialogue]. Moscow, Nauka Publ., 2007. 302 p. In Russian. 
Sultanov K. K. Ugol prelomleniya. Literatura i identichnost': kommunikativnyi aspekt. [The angle of refraction. Literature and identity: the communicative aspect]. Moscow, IMLI RAN Publ., 2019. 352 p. In Russian.

Tarkhanov A. Den' boren'ya: Stikhi, poemy [Struggle Day: poems]. Ekaterinburg: Sredne-Ural'skoe knizhnoe izdatel'stvo Publ., 2005. 319 p. In Russian.

Khazankovich Yu. G. Fol'klorno-epicheskie traditsii v proze malochislennykh narodov Severa Severa [Folklore-epic traditions in prose of indigenous small-numbered peoples of the North]. Novosibirsk, Izd-vo SO RAN Publ., 2009. 131 p. In Russian.

Khazankovich Yu. G. Epicheskie traditsii v proze korennykh malochislennykh narodov Arktiki [Epic traditions in prose of indigenous small-numbered peoples of the Arctic]. Moscow, Flinta Publ., 2020. 416 p. In Russian.

Domokos P. Itäisten suomalais-ugrilaisten kansojen kirjallisuudesta. Porvoo: SKS, 1983. 179 p. In Finnish.

Grönstrand H. Self-translating: linking languages, literary traditions and cultural spheres - Cosmopolitanism and Transnationalism: Visions, Ethics and Practices. Helsinki: Helsinki Collegium for Advanced Studies. 2014. Vol. 15. Pp. 116-137. In English.

Kurki T. Rajan kirjailijat. Venäjän Karjalan suomenkieliset kirjailijat tilan ja identiteetin kirjoittajina. Helsinki: SKS, 2018. 436 p. In Finnish.

Waite G. Nancy Huston's Polyglot Texts: Linguistic Limits and Transgressions - L2 Journal, 2015. Vol. 7. Pp. 102-113. In English.

Yildiz Y. Beyond the mother tongue. The postmonolingual condition. New York: Fordham University Press, 2012. 306 p. In English.

Arzamazov Alexey Andreevich, Doctor of Philology, Leading Researcher Udmurt Institute of History, Language and Literature Udmurt Federal Research Center of UB RAS

4, ul. Lomonosova, Izhevsk, 426004, Russian Federation

Doctor of Philology, Leading Researcher Laboratory of the multiple-factor humanitarian analysis and cognitive philology Federal research center "Kazan Scientific Center of the Russian Academy of Sciences" 2/31, ul. Lobachevskogo, Kazan, 420111, Russian Federation e-mail: arzami@rambler.ru 